\title{
FOSTERING EXTERNAL AND INTERNAL SUSTAINABILITY WITHIN THE ENGLISH FOR ACADEMIC PURPOSES COURSE IN THE COVID-19 PANDEMIC
}

\author{
Andreas Ahrens ${ }^{1}$, Jelena Zascerinska ${ }^{2}$, Anastasija Aleksejeva ${ }^{3}$ \\ ${ }^{1}$ Hochschule Wismar University of Applied Sciences Technology Business and Design, \\ Germany \\ ${ }^{2,3}$ Centre for Education and Innovation Research, Latvia
}

\begin{abstract}
The paper aims to explore sustainability from both the external and internal perspectives underpinning the implementation of the empirical study within an English for Academic Purposes course at a Master level in the COVID-19 pandemic. The research is based on the methodology of the development of the system of the external and internal perspectives. The exploratory type of the case study was employed. The interpretive paradigm was used in the research. The observation was conducted on the $23^{\text {rd }}$ August 2020. The sample was composed of the 10 international students of the Master programme "Information and Electrical Engineering" at Hochschule Wismar, Germany. The theoretical research defines the external and internal sustainability. The empirical finding is that the COVID-19 pandemic has influenced the organizational aspect of the English for Academic Purposes course (timetable, classroom arrangements, group work organization). Another finding is that the implemented English for Academic Purposes course is partially sustainable and requires its dynamic equilibrium and localized robustness to be adjusted. Implications for higher education aimed at increasing both the external and internal sustainability in education imply the implementation of the combination of evaluation, namely external evaluation, mutual evaluation, and self-evaluation, jointly carried out by all the process participants.
\end{abstract}

Keywords: COVID-19 pandemic, English for Academic Purposes Course, External Perspective, Internal Perspective, International Students, Master Degree, Sustainability.

To cite this article:

Ahrens, A., Zascerinska, J., \& Aleksejeva, A. (2021). Fostering External and Internal Sustainability within the English for Academic Purposes Course in the Covid-19 Pandemic. Education. Innovation. Diversity, 2(2), 6-15. DOI: https://doi.org/10.17770/eid2021.1.5412

\section{Introduction}

The COVID-19 pandemic has tremendously impacted the sustainability of many people life. A lot of people had to adjust themselves to the overnight transformations in their working life, family conditions, and social environments including higher education. Higher education has been significantly adapting to the new conditions created by the COVID-19 pandemic. In higher education, the COVID-19 pandemic was a cause of universities' lockdown, rapid shift from on-campus education to digital studies, unprecedentedly fast transfer of printed teaching materials to their digital format, etc. Nevertheless, sustainability remains an important parameter in education in general and an English for Academic Purposes course as part of higher education at master level. Sustainability refers to stability (Emas, 2015). Sustainability is characterized by a dynamic equilibrium and localized robustness, applied to the current status of the affair (Antonini, 1999). Sustainability dynamics is influenced by fluid conditions (Antonini, 1999) or, in other words, factors (Ahrens \& Zaščerinska, 2014a).

The methodological foundation of the present research is formed by the SystemConstructivist Theory. The System-Constructivist Theory implies that the world is constructed in modules (Maslo, 2006). New Constructivism supposes that any understanding is not separated from the observer, and reality is socially constructed (Maslo, 2006). Constructing is a creative process that includes a diversity of meaning understanding to offer a variety of 
opportunities to construct mankind development (Maslo, 2006). Constructive process is always situative (Lamberigts \& Dīpenbroks, 2004). Cognitive process is considered by the Pedagogical Theory of Social Constructivism to be a component of the construction process: a perception is not right or wrong but whether it is relevant to a place or conditions (Maslo, 2006). The SystemConstructivist Theory emphasizes that human being's point of view depends on the subjective aspect (Zaščerinska, 2010). Everyone has his/her own system of the external and internal perspectives (Zaščerinska, 2010). This system of the external and internal perspectives is a complex open system (Zaščerinska, 2010). Experience plays the central role in a construction process (Maslo, 2007).

The present work is based on the methodology of the development of the system of the external and internal perspectives as demonstrated in Figure 1 (Ahrens \& Zaščerinska, 2010).
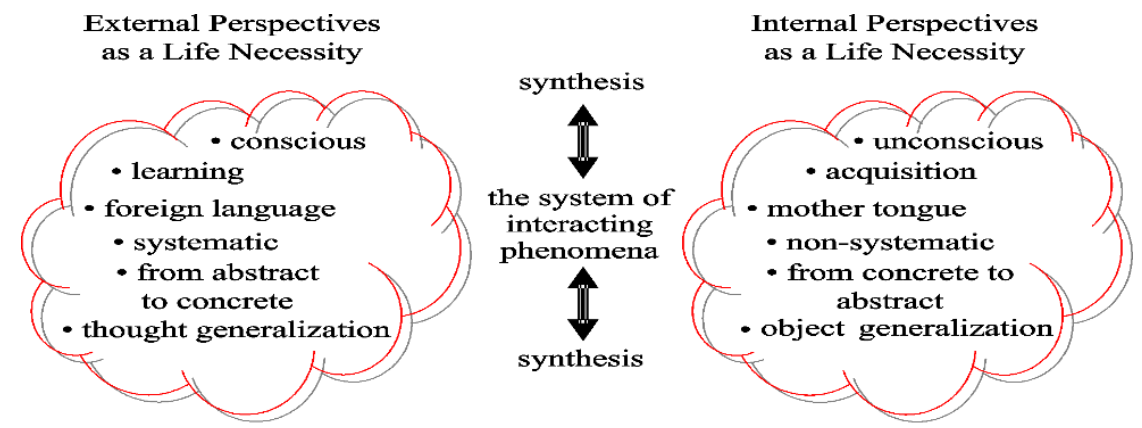

Figure 1 Development of the system of the external and internal perspectives (Ahrens \& Zaščerinska 2010)

The methodology of the development of the system of the external and internal perspectives proceeds from the external perspective through the phase of the unity of the external and internal perspectives (the system of the interacting phenomena) to the internal perspective as illustrated in Figure 2 (Ahrens \& Zaščerinska, 2012a).

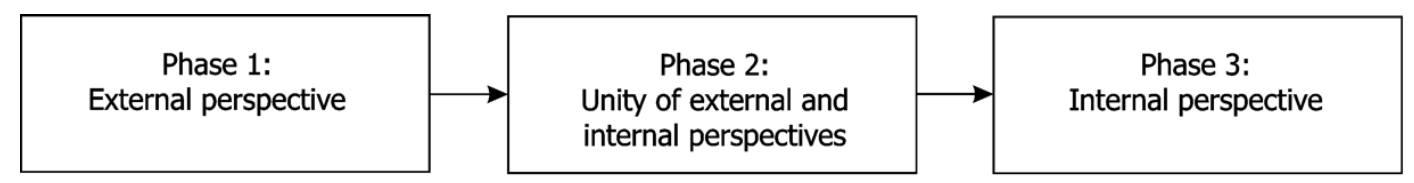

Figure 2 Phases of the development of the system of the external and internal perspectives (Ahrens \& Zaščerinska, 2012a)

The published research has established the inter-connections between sustainable development and higher education putting the emphasis on a student, individual and personality (Ahrens \& Zaščerinska, 2012a; Ahrens \& Zaščerinska, 2012b; Pappas \& Pappas, 2015), thereby from the internal perspective. The external perspective of sustainability has not attracted a lot of researchers' attention. However, the external and internal perspectives are inter-connected: sustainable personality is a person who is able to develop the system of the external and internal perspectives, and, in turn, the system of the external and internal perspectives becomes a main condition for the sustainable personality to develop (Ahrens \& Zaščerinska, 2010, p. 180). Consequently, sustainability has to be considered as the system of the external and internal perspectives.

The enabling research question is: How to foster sustainability from both the external and internal perspectives in higher education? The paper aims to explore sustainability from both the external and internal perspectives underpinning the implementation of the empirical study within an English for Academic Purposes course at a Master level in the COVID-19 pandemic. 
The present research was of the qualitative nature. The applied research methods included the use of theoretical as well as empirical methods. The theoretical methods implied the analysis of theoretical sources and theoretical modelling (Ahrens, Zascerinska, \& Melnikova, 2019). The case study research was applied as "case studies [...] are generalizable to theoretical propositions and not to populations or universes. In doing a case study, your goal will be to generalize theories (analytical generalization) and not to enumerate frequencies (statistical generalization)" (Yin, 2003, p. 10). Case study research is a qualitative research design (Kohlbacher, 2005). The exploratory study was implemented within the empirical analysis. The empirical study was carried out with the 10 international engineering master students of the English for Academic Purposes course within the Master programme "Information and Electrical Engineering" at Hochschule Wismar, Germany. The data were collected via observation. The gathered data were interpreted and summarised.

\section{Conceptual Framework}

The relationships between sustainability and education are often defined as Education for Sustainable Development (ESD). Against this background, education for sustainable development is differentiated from sustainable education in this work. By sustainable education, English for Academic Purposes course is meant in the present research. In turn, education for sustainable development focuses on student's knowledge, skills and attitudes. As reflected in Figure 3, the methodology of the system of the external and internal perspectives implies that sustainable education, namely English for Academic Purposes, refers to the external perspective, and education for sustainable development, namely student's knowledge, skills and attitudes, relates to the internal perspective.

\begin{tabular}{|c|c|}
\hline \multicolumn{2}{|c|}{ The system of the external and internal perspectives } \\
\hline External perspective & Internal perspective \\
\hline Sustainable education & Education for sustainable development \\
\hline English for Academic Purposes course & Student's knowledge, skills and attitudes \\
\hline
\end{tabular}

Figure 3 The inter-relations between the research methodology as well as sustainable education and education for sustainable development (the authors)

Student's knowledge, skills and attitudes within a Master Degree programme are delivered via a course. The English for Academic Purposes course within the Master programme "Information and Electrical Engineering" is based on the educational process (Zaščerinska, 2009a) or, in other words, activity. The educational process proceeds from teaching in Phase 1 through peer-learning in Phase 2 to learning in Phase 3 (Zaščerinska, 2011). Each phase of the educational process is separated from the previous one, and the following phase is based on the previous one (Zaščerinska, 2011). Phase 1 is aimed at a safe environment for all the students. This phase is organized in a frontal way involving the students to participate. Phase 2 is designed for the students' analysis of an open professional problem situation and their search for a solution based on students' peer-learning (Zaščerinska \& Ahrens 2010, p. 185). Phase 3 emphasizes the students' self-regulation with the use of assessment of the process and self-evaluation of the results. The students present their self-evaluation by the end of each class. Students gradually proceed from the external regulation and evaluation in Phase 1 through mutual evaluation in Phase 2 to self-regulation and self-evaluation in Phase 3 (Ahrens \& Zaščerinska, 2012a).

Both the English for Academic Purposes course as well as student's knowledge, skills and attitudes are closely related to evaluation (Zaščerinska, 2013). Evaluation consists of 
external evaluation, mutual evaluation, and self-evaluation (Zaščerinska, 2013). Evaluation includes a variety of forms: questionnaire, interview, focus group interview, etc. Evaluation is measured via attitude. Attitude can be differentiated into positive, neutral or negative (Ahrens \& Zaščerinska, 2014b). The methodology of the system of the external and internal perspectives allows establishing the inter-connections between the external and internal perspectives as well as students' negative and positive attitudes/impressions/emotions, respectively as depicted in Table 1.

Table 1 The inter-relations between the external and internal perspectives as well as students' negative and positive attitudes/impressions/emotions

\begin{tabular}{|c|c|}
\hline External perspective & Internal perspective \\
\hline Negative attitude & Positive attitude \\
\hline \multicolumn{2}{|c|}{ The system of the external and internal perspectives } \\
\hline
\end{tabular}

The negative attitude is considered as the external perspective, while the positive impressions - as the internal perspective. This can be explained as following: if students have not enriched their knowledge, skills and attitudes, then, they express a negative attitude, and the English for Academic Purposes course needs an adjustment that will ensure a dynamic equilibrium and localized robustness of the course. If students have developed their knowledge, skills and attitudes, then, they show positive emotions or, in other words, attitude (Ahrens \& Zaščerinska, 2014b), and the English for Academic Purposes course has demonstrated its sustainability.

\section{Methodology}

The methodology of the present empirical study was led by the enabling study question: What is the international engineering students' evaluation of the English for Academic Purposes course? The empirical study was aimed at evaluating the English for Academic Purposes course of the Master programme "Information and Electrical Engineering" at Hochschule Wismar, Germany. It should be pointed that the English for Academic Purposes is defined as content and research integrated studying (Zaščerinska, 2008). The definition of English for Academic Purposes as content and research integrated studying provides us with two main topics to be covered within an English for Academic Purposes course: a subject content (engineering, medicine, nature, etc) and language research skills (Zaščerinska, 2008). Two main topics, namely a subject content (engineering, medicine, nature, etc) and language research skills, include sub-topics as demonstrated in Figure 1.

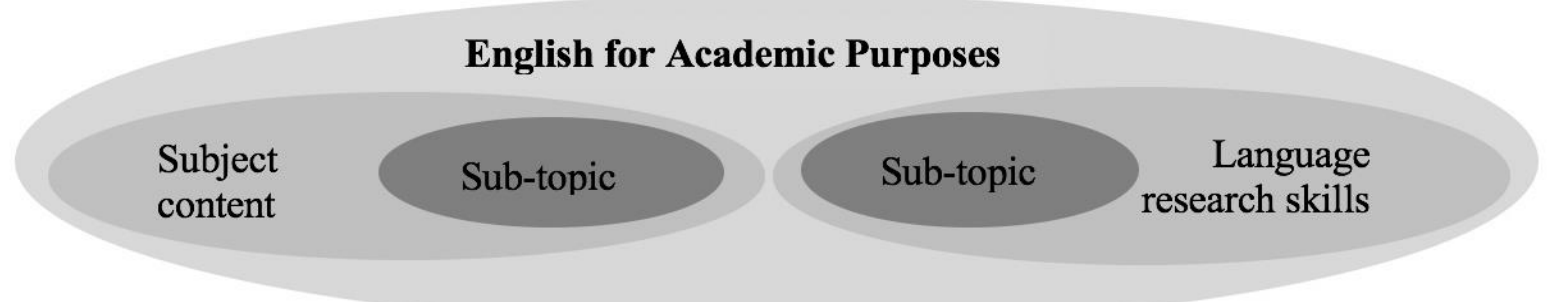

Figure 1 The relationship between English for Academic Purposes, its two main topics and sub-topics (the authors) 
The sub-topics for the English for Academic Purposes course were selected, based on the authors' research results, and logically introduced by the authors of the present contribution: Introduction into presentation preparation (Zaščerinska, 2009b, p. 160), Academic communication (Gruenwald, Ahrens, Zaščerinska, Melnikova, \& Andreeva, 2018), Passive Voice (Zascerinska, Aleksejeva, Zascerinskis, Gukovica, \& Aleksejeva, 2020), Presentation skills via making three presentations on students' native place, a researcher biography, and students' term/course papers (Ahrens \& Zascerinska, 2020), Problem Solving (Zaščerinska \& Zaščerinskis, 2012), Information and Ideas, Reading sub-skills, Writing own biography (Ahrens, Zaščerinska, \& Melnikova, 2019), Academic writing with the focus on master thesis and scientific publication (Ahrens \& Zascerinska, 2020).

The present empirical study was carried out on the 23rd August 2020. The time of the implementation of the English for Academic Purposes course was between the 1st and 2nd waves of the COVID-19 pandemic. Due to the restrictions set by Hochschule Wismar, namely to keep the distance of two meters between two students as well as other similar limitations, the organisational structure of the English for Academic Purposes course was adapted in accordance with the new regulations. The English for Academic Purposes course was implemented only on Saturdays and Sundays. A typical Saturday (on Saturday, the students could buy a lunch from a supermarket as all the shops are open for customers in Germany) was scheduled such as Lecture 1 - 09:00-10:30am, Lunch time - 10:30-11:00am, Lecture 2 - 11:0012:30pm, Lecture $3-12: 45-14: 15 \mathrm{pm}$. A typical Sunday (on Sundays all the shops are closed with the exception of McDonalds, etc) was planned as following: 09:00-10:30am - Lecture 1, 10:30-10:45am - Lunch time, 10:45-12:15pm - Lecture 2, 12:30-14:00pm - Lecture 3. Along with the classes on the weekends, the students had to follow the requirement to keep the distance of about two meters being in the classroom. As the key method for organizing students' work in a language class is peer-learning or, in other words, group work, a language classroom traditionally chosen is of not a big size. In the COVID-19 pandemic, in order to ensure the distance of two meters between the class participants, namely students and teacher, a big lecture hall was selected for language classes' delivery. In a language class, two students usually sit next to each other at the same desk. Against this, the international students had to take a desk alone. Such an organization of the students in the classroom was not convenient to organize a group work among the students. For the implementation of the group work, the students had to increase the volume of their voices, to use a notebook for demonstrating what they wrote, even mobile phones were utilized for a discussion via sending a message.

The exploratory type of the case study research has been applied (Zainal, 2007) in the present empirical study as case studies have an important function in generating new research questions, hypotheses and building theory (Kohlbacher, 2005). Exploratory case studies set to explore any phenomenon in the data which serves as a point of interest to the researcher (Zainal, 2007). The exploratory methodology proceeds from exploration in Phase 1 through analysis in Phase 2 to hypothesis/question development in Phase 3 (Ahrens, Bassus, \& Zaščerinska, 2013). Phase 1 Exploration is aimed at data collection, Phase 2 Analysis focuses on data processing, analysis and interpretation, and Phase 3 Hypothesis Development is oriented to the analysis of results of the empirical study and elaboration of conclusions and hypotheses for further research (Hariharan, Zaščerinska, \& Swamydhas, 2013).

The interpretive research paradigm was used in the study. The interpretive paradigm is characterized by the researcher's practical interest in the research question (Cohen, Manion, \& Morrison, 2003). The interpretive paradigm is featured by the researcher's interest in a phenomenon. The interpretive paradigm is aimed at analysing the social construction of the meaningful reality. Meanings emerge from the interpretation. The researcher is the interpreter (Ahrens, Purvinis, Zaščerinska, Miceviciene, \& Tautkus, 2018). 
The observation was carried out for data collection. Observation is a highly effective method of qualitative data obtaining (Zaščerinska, 2013). Observation makes use of a number of techniques, namely respondent interviewing and students' self-analysis (McCall, \& Simmons, 1969 , p. 1). Moreover, observation contributes to a more adequate picture that emerges of the research setting as a social system described from a number of participants' perspectives (Geertz, 1973). Furthermore, Hargreaves (Hargreaves, 1967, p. 193) described advantages of participant observation as a research method for those carrying out studies in institutions in which they work: the method of participant observation leads the investigator to accept a role within the social situation $\mathrm{s} / \mathrm{he}$ studies $-\mathrm{s} / \mathrm{he}$ participates as a member of the group while observing it. In theory, this direct participation in the group life permits an easy entrance into the social situation by reducing the resistance of the group members; decreases the extent to which the investigator disturbs the 'natural' situation, and permits the investigator to experience and observe the group's norms, values, conflicts and pressures, which (over a long period) cannot be hidden from someone playing an in-group role (Hargreaves, 1967, p. 193). The observation focused on what the students liked and did not like in the English for Academic Purposes course. The observation aimed at the evaluation combination, namely external evaluation, mutual evaluation, and students' self-evaluation. The collected data were processed via the structuring content analysis and the summarizing content analysis (Mayring, 2000). The structuring content analysis assists in categorising the data in accordance to the previously determined criteria (Budde, 2005). In turn, the summarizing content analysis seeks to reduce the material in such a way that the essential contents are preserved, but a manageable short text is produced (Mayring, 2004, p. 269).

The sample was composed on the principles of sample appropriateness, sufficiency and confidence (Ahrens \& Zaščerinska, 2015). The sample was composed of the 10 international engineering students of the Master programme "Information and Electrical Engineering" at Hochschule Wismar, Germany. By international students, "a third-country national accepted by an establishment of higher education and admitted to the territory of a Member State to pursue as his/her main activity a full-time course of study leading to a higher education qualification recognised by the Member State, (...) which may cover a preparatory course prior to such education according to its national legislation" (Mayer, Yamamura, Schneider, \& Müller, 2012) is meant. It should be noted that the Master programme "Information and Electrical Engineering" at Hochschule Wismar involves the students mostly from India. The Master programme "Information and Electrical Engineering" for international students is popular at Hochschule Wismar in Germany, as it ensures such economic resources, that influence the regional economics, as labour and entrepreneurship (Ahrens et al., 2018). All the students who participated in the empirical study have obtained a Bachelor Degree in electrical engineering in different universities of different regions of India.

\section{Research Results}

Table 2 summarizes the results of the empirical study.

Table 2 Results of the students' evaluation of the English for Academic Purposes course

\begin{tabular}{|c|c|}
\hline Positive attitude & Negative attitude \\
\hline Internal perspective & External perspective \\
\hline Never radio type & $\begin{array}{c}\text { More focus on academic writing (than on } \\
\text { presentation) }\end{array}$ \\
\hline Informative content (by three students) & More content on the master thesis \\
\hline Well-organised group work (by two students) & More time should be given for the course \\
\hline Presentation preparation & To avoid classes on Saturdays and Sundays \\
\hline
\end{tabular}




\begin{tabular}{|c|c|}
\hline Learnt new things in a professional way & $\begin{array}{c}\text { Short period (for the course) } \\
\text { Limited period (by two students) }\end{array}$ \\
\hline \begin{tabular}{c} 
Presentation and structuring of master thesis are well $\begin{array}{c}\text { Explained } \\
\text { expled }\end{array}$ \\
\cline { 2 - 2 }
\end{tabular} & Vast topics included in short time \\
\cline { 2 - 2 } & The course should be more interactive \\
\hline
\end{tabular}

Source: by the authors

$n=10$

The findings of the study were withdrawn via the implementation of the content analysis (Ahrens, Foerster, Zaščerinska, \& Wasser, 2020). The data were categorized in accordance to the methodology of the system of the external and internal perspectives as revealed in Figure 5. The structuring content analysis allows identifying that the students' positive attitude refers to the internal perspective. The student's positive evaluation, namely "Learnt new things in a professional way", validates our hypothesis that if students have developed or, in other words, learnt their knowledge, skills and attitudes, then, they show the positive attitude, and the English for Academic Purposes course has demonstrated its sustainability. In turn, the negative attitude is considered as the external perspective. This hypothesis also has found a validation as a couple of the students evaluated the course in the following way: "More focus on academic writing (than on presentation)", "More content on the master thesis", and "the course should be more interactive". The last evaluation is in contradiction with the other student's evaluation, namely "Never radio type". Consequently, our hypothesis, namely if students have not enriched their knowledge, skills and attitudes, then, they express a negative attitude, is valid.

The structuring content analysis has contributed to the finding that the English for Academic Purposes course needs an adjustment, that will ensure a dynamic equilibrium and localized robustness of the course, in regard to the students' evaluations, namely to avoid classes on Saturdays and Sundays, vast topics included in a short period of time, and break time (too early for lunch). The sustainability of the English for Academic Purposes course could be increased via the re-consideration of the volume and segregation of the delivered topics during the course.

The summarizing content analysis allows concluding that fostering of both the external and internal sustainability is based on the methodology of the development of the system of the external and internal perspectives. Another finding is that both the external and internal sustainability are ensured via the implementation of the combination of evaluation, namely external evaluation, mutual evaluation, and self-evaluation. The evaluation is jointly carried out by the students and teacher.

\section{Conclusions}

The theoretical research results in the definition of the external and internal sustainability. Another finding is that both the external and internal sustainability are ensured via the implementation of the combination of evaluation, namely external evaluation, mutual evaluation, and self-evaluation, jointly carried out by all the process participants.

The empirical study validated the finding that the positive attitude refers to the internal perspective, while negative attitude - to the external perspective. Another finding is that the COVID-19 pandemic has influenced the organizational aspect of the English for Academic Purposes course (timetable, classroom arrangements, group work organization). The interpretive paradigm applied to the empirical study allows drawing a conclusion that the implemented English for Academic Purposes course is partially sustainable and requires its dynamic equilibrium and localized robustness of the course to be adjusted.

Implications for higher education aimed at increasing both the external and internal sustainability include the recommendation to implement the combination of evaluation, namely 
external evaluation, mutual evaluation, and self-evaluation, jointly carried out by all the process participants.

The research has some limitations. The limitation is the inter-connections between the external and internal sustainability and the methodology of the development of the system of the external and internal perspectives. Another limitation is the involvement of only one group of international students of one Master programme at one higher education institution in one country in the empirical study.

Further research will tend to increase the number of respondents as well as the involvement of participants from different educational institutions. Enhancement of the proposed methodology and theoretical background will be carried out. Comparative studies of theoretical elaborations and empirical data will attract a lot of research interest in the scientific community, too.

\section{References}

Ahrens, A. \& Zascerinska, J. (2020). Comparison of Teacher's and Students' Ranking of English for Academic Purposes Sub-Topics. Education. Innovation. Diversity, 1(1), 1625. DOI: http://dx.doi.org/10.17770/eid2020.1.5328.

Ahrens, A., \& Zaščerinska, J. (2010). Social Dimension of Web 2.0 in Student Teacher Professional Development. Proceedings of Association for Teacher Education in Europe Spring Conference 2010: Teacher of the 21st Century, Quality Education for Quality Teaching, 179-186.

Ahrens, A., \& Zaščerinska, J. (2012a). Perspective of Game Theory in Sustainable Development. ATEE Spring University 2012: Conference 20 Years of Sustainable Development: Learning from Each Other, 99-108.

Ahrens, A., \& Zaščerinska, J. (2012b). Sustainable Development in Engineering Education: A Pedagogical Approach. ATEE Spring University 2012: Conference 20 Years of Sustainable Development: Learning from Each Other, 115-130.

Ahrens, A., \& Zaščerinska, J. (2014a). A Framework for Selecting Sample Size in Educational Research on e-Business Application. Proceedings of ICE-B 2014 11th International Conference on E-Business, 31-38.

Ahrens, A., \& Zaščerinska, J. (2014b). Students' Attitude to Interdisciplinary Research. Proceedings of the International Scientifical Conference Society, Integration, Education. Volume I: Higher Education Institutions Pedagogy, School Pedagogy, Pre-School Pedagogy, 13-23. DOI: https://doi.org/10.17770/sie2014vol1.737

Ahrens, A., \& Zaščerinska, J. (2015). Principles of Sampling in Educational Research in Higher Education. Proceedings of the International Scientifical Conference Society, Integration, Education, Volume 1 Higher Education Pedagogy, 25-35. DOI: https://doi.org/10.17770/sie2015vol1.310

Ahrens, A., Bassus, O., \& Zaščerinska, J. (2013). Bi-professional Curriculum in Higher Education: Context Analysis. Proceedings of 6th ICEBE International Conference on Engineeirng and Business Education Innovation, Entrepreneurship and Sustainability, 101-107.

Ahrens, A., Foerster, M., Zaščerinska, J., \& Wasser, I. (2020). European Accreditation Agency's View on Kazakhstan's Engineering and Information Technology Higher Education. Society. Integration. Education. Proceedings of the International Scientific Conference. Volume V, 15-25. DOI: http://dx.doi.org/10.17770/sie2020vol1.4861

Ahrens, A., Grünwald, N., Bassus, O., Andreeva, N., Zaščerinska, J., \& Melnikova, J. (2018). Impact of Master Programme "Information and Electrical Engineering" for International 
Students at Hochschule Wismar on Regional Economics: Theoretical Modelling. Perspectives of Economics of Kaliningrad Region and EU Development, 6-9.

Ahrens, A., Purvinis, O., Zaščerinska, J., Micevičienè, D., \& Tautkus, A. (2018). Burstiness Management for Smart, Sustainable and Inclusive Growth: Emerging Research and Opportunities. IGI Global. DOI: 10.4018/978-1-5225-5442-4.

Ahrens, A., Zaščerinska, J., \& Melnikova, J. (2019). Method for the Construction of Students' Scientific Identity within English for Academic Purposes: The Case of International Students of Master Programme "Information and Electrical Engineering" at Hochschule Wismar. Society. Integration. Education. Proceedings of the International Scientific Conference, Volume I, 43-53. DOI: http://dx.doi.org/10.17770/sie2019vol1.3731.

Antonini, C.D. (1999). Definition of Stability in International Relations. 14th World Congress of IFAC.

Budde, R. (2005). Mexican and Central American L.A. Garment Workers: Globalized Industries and their economic constraints. LIT Verlag Münster.

Cohen L., Manion L., \& Morrsion K. (2003). Research Methods in Education. London and New York: Routledge/Falmer Taylor \& Francis Group.

Emas, R. (2015). The Concept of Sustainable Development: Definition and Defining Principles. Brief for GSDR 2015. In: Global Sustainable Development Report, United Nations.

Geertz, C. (1973). The Interpretation of Cultures. London: Hutchinson.

Gruenwald, N., Ahrens, A., Zaščerinska, J., Melnikova, J., \& Andreeva, N. (2018). SocioCultural Adaptation of International Students of Master Programme "Information and Electrical Engineering" at Hochschule Wismar. Proceedings of the 5th International Scientific Conference on "Modern Economics", 33-39.

Hargreaves, D. H. (1967). Social Relations in a secondary school. London: Routledge and Kegan Paul.

Hariharan, R., Zaščerinska, J., \& Swamydhas, P. (2013). A Comparative Study of Methodologies of Teaching Web Technologies to Prospective Teachers in India and Latvia. International Journal of Modern Education Forum (IJMEF), Volume 2, Issue 4. 84-91. Print ISSN 2324-6928, online ISSN 2324-6944.

Kohlbacher, Florian (2005). The Use of Qualitative Content Analysis in Case Study Research. Forum: Qualitative Social Research, 7(1), Art. 21.

Lamberigts, R., \& Dīpenbroks, J.-V. (2004). Aktīvās mācības kooperatīiā mācību vidē: eksperimenta īstenošana un rezultāti. [Active learning in cooperative learning environment: conducting of an experiment and its results]. Kooperatīvā mācīšanās, 106116.

Maslo, I. (Ed.) (2006). No zināšanām uz kompetentu darbību [From knowledge to competent activity]. Latvijas Universitātes Akadēmiskais apgāds, 148-161.

Maslo, E. (2007) Transformative Learning Space for Life-Long Foreign Languages Learning. In: D.Cunningham, D.Markus, J.Valdmanis et al. (Eds). International Nordic-Baltic Region Conference of FIPLV Innovations in Language Teaching and Learning in the Multicultural Context (pp. 38-46). Rīga: SIA "Izglītības soḷi".

Mayer, M.M., Yamamura, S., Schneider, J., \& Müller, A. (2012). Immigration of International Students from Third Countries. Study by the German National Contact Point for the European Migration Network (EMN). Bonn, Germany: Federal Office for Migration and Refugees 2012.

Mayring, P. (2000). Qualitative Content Analysis. Forum: Qualitative Social Research, 1(2), Art. 20.

Mayring, P. (2004). Qualitative Content Analysis. In: U. Flick, E. Von Kardoff and I. Steinke (Eds). A Companion to Qualitative Research (pp. 266-269). SAGE, UK, Glasgow. 
McCall, G.J. and Simmons, J.L. (eds.) (1969). Issues in Participant Observation, Reading, Mass. Addison Wesley.

Pappas, J.B., \& Pappas, E.C. (2015). The Sustainable Personality: Values and Behaviors in Individual Sustainability. International Journal of Higher Education, Vol. 4, No. 1; $12-$ 21. DOI: https://doi.org/10.5430/ijhe.v4n1p12

Yin, R.K. (2003). Case study research, design and methods (3rd ed., vol. 5). Thousand Oaks: Sage.

Zainal, Zaidah (2007). Case study as a research method. Jurnal Kemanusiaan bil.9, Jun 2007.

Zaščerinska, J. (2008). Research within English for Academic Purposes Studies. In: the database of the European Conference on Educational Research from Teaching to Learning the 10th-12th September 2008 Gothenborg, Sweden. Retrieved from the EERA databank: www.eera-ecer.eu/fileadmin/user.../ECER2008_182_Zascerinska.doc .

Zaščerinska, J. (2009a). Organisation of English for Academic Purposes Activity for Developing Communicative Competence. Journal of International Scientific Publications: Language, Individual \& Society, Volume 3, 140-173.

Zaščerinska, J. (2009b). The Use of the Internet and Powerpoint in Promoting Student Teachers' Communication Competence within the English for Specific Purposes Course. Citizenship, Social and Economics Education, 8 (2 \& 3), 152-163. DOI: http://dx.doi.org/10.2304/csee.2010.8.2.152

Zaščerinska, J. (2010). Professional Environment for Teacher Professional Development. Proceedings of 5th International scientific conference Theory for Practice in the Education of Contemporary Society, 396-402.

Zaščerinska, J. (2011). How to Teach Content: Existing Concepts and Prospects for Development. ATEE Spring University 2011: Changing Education in a Changing Society, Volume 1, 134-149.

Zaščerinska, J. (2013). Development of Students' Communicative Competence within English for Academic Purposes Studies. Verlag: Mensch \& Buch.

Zaščerinska, J., \& Ahrens, A. (2010). Social Dimension of Web 2.0 in Teacher Education: Focus on Peer-Learning. Proceedings of London International Conference on Education September 6-8, 182-187.

Zaščerinska, J., \& Zaščerinskis, M. (2012). Problem Solving in Student Police Officers' Professional Development. Proceedings of the I International scientific conference „Legal, Sociological and Psychological Aspects of Human Safety”. 251-262..

Zascerinska, J., Aleksejeva, L., Zascerinskis, M., Gukovica, O., \& Aleksejeva, A. (2020). Language Guidelines on Students' Biography Writing as a Means of Self-Presentation for Recruitment and Employment. International Applied Research Conference Proceedings Challenges and Social Responsibility in Business, 12-21. 